\title{
PELAPORAN PAJAK PENGHASILAN PELAKU USAHA KECIL DAN MENENGAH DI DESA KARANGKUTEN KECAMATAN GONDANG KABUPATEN MOJOKERTO
}

\author{
Aristha Purwanthari Sawitri ${ }^{*}$, Rina Fariana ${ }^{2}$, Bayu Adi $^{3}$, Suhariyanto ${ }^{4}$, Martha Suhardiyah $^{5}$ \\ 1,2,3,4,5 Fakultas Ekonomi, Universitas PGRI Adi Buana, Jl. Dukuh Menanggal XII No.37, Surabaya \\ Email: 1aristha@unipasby.ac.id; 2rina@unipasby.ac.id; 3bayu@unipasby.ac.id; ${ }^{4}$ suhariyanto@unipasby.ac.id; \\ ${ }^{5}$ martha@unipasby.ac.id \\ *Penulis korespondensi
}

\begin{abstract}
Abstrak: Guna mempermudah dalam melakukan penghitungan pajak dan pelaporannya secara self assesment maka pelaku UMKM perlu melakukan penyusunan pelaporan fiskal. Dalam penyusunan pelaporan fiskal didasarkan atas pelaporan keuangan komersial yang disesuaikan dengan peraturan perpajakan. Bagi pelaku UMKM dapat menggunakan dasar Standar Akuntansi Keuangan Untitas Tanpa Akuntabilitas Publik (SAK-ETAP) yang telah dibuat oleh Ikatan Akuntan Indonesia. Desa Karang Kuten Kecamatan Gondang Kabupaten Mojokerto merupakan desa yang memiliki banyak potensi dan UMKM. Pada desa ini ditemukan bahwa pelaku UMKM masih banyak yang belum memiliki pemahaman mengenai pajak terutama belum memahami perhitungan pajak yang harus dibayar serta belum memahami pembuatan pelaporan pajak. Berdasarkan permasalahan yang dihadapi oleh pelaku UMKM, maka tim dosen memberikan solusi atas permasalahan yang ditemukan antara lain memberikan pelatihan penyusunan laporan keuangan sederhanan guna membantu pelaku UMKM. Metode yang digunakan dalam kegiatan pengabdian ini pertama sosialisasi, kedua pelatihan dan ketiga pendampingan. Hasil kegiatan pengabdian kepada masyarakat adalah pelaku UMKM telah mampu untuk menyusun laporan keuangan untuk mengetahui jumlah omzet, pelaku UMKM telah mampu menghitung pajak penghasinal final dan menyusunan laoran fiskal sebagai dasar penghitungan pajak penghasilan kepada pengusaha UMKM di Desa Karang Kuten Kecamatan Gondang Kabupaten Mojokerto. Dengan pelaksanaan kegiatan pengabdian ini dapat meningkatkan kesadaran untuk menjalankan kewajibannya dalam membayar pajak.
\end{abstract}

Kata kunci: PPh final, UMKM, pelaporan pajak.

\begin{abstract}
In order to make it easier to do tax calculation and self-assessment reporting, MSME actors need to prepare fiscal reporting. In the preparation of fiscal reporting based on commercial financial reporting adjusted to tax regulations. MSMEs can use the basis of the Financial Accounting Standards without Public Accountability (SAK-ETAP) that has been made by the Indonesian Institute of Accountants. Karang Kuten Village Gondang District Mojokerto Regency is a village that has a lot of potential and MSMEs. In this village, it was found that there were still many SMEs who did not have an understanding of taxes, especially not understanding the calculation of taxes to be paid and did not understand making tax reporting. Based on the problems faced by SMEs, the lecturer team provides solutions to the problems found, among others, providing training in preparing financial statements to help MSME entrepreneurs. The method used in this community service activity is firstly socializing, secondly training and thirdly mentoring. The results of community service activities are that MSMEs have been able to compile financial reports to find out the turnover, MSMEs have been able to calculate the final criminal tax and compile a fiscal report as a basis for calculating income tax for MSME entrepreneurs in Karang Kuten Village, Gondang District, Mojokerto Regency. By carrying out this service activity, it can increase awareness to carry out its obligations in paying taxes.
\end{abstract}

Keywords: Final income tax, UMKM, tax reporting. 


\section{PENDAHULUAN}

Usaha Mikro, Kecil dan Menengah (UMKM) merupakan pelaku kunci keberhasilan dalam pembangunan ekonomi nasional. Pelaku UMKM setiap tahunnya mengalami peningkatan, berdasarkan data Badan Pusat Statistik pada tahun 2012 UMKM di Jawa Timur mengalami kenaikan menjadi 6.800.000 pelaku UMKM dan di tahun 2018 mengalami kenaikan menjadi 9.590 .000 pelaku UMKM. Berdasarkan data Dinas Koperasi dan UMKM, peningkatan jumlah UMKM salah satunya yaitu UKM Mojokerto yang mencapai 155.354 unit pelaku. Dengan semakin banyaknya pelaku UMKM setiap tahunnya, maka persaingan produk UMKM dan risiko usaha juga akan mengalami kenaikan. Usaha mikro, kecil dan menengah merupakan sektor ekonomi yang memberikan kontribusi terhadap Produksi Domestik Bruto (PDB), tetapi ini tidak sejalan dengan penerimaan pajak. Salah satu penyebabnya yaitu masih kurangnya kesadaran pelaku UMKM untuk memenuhi kewajiban perpajakan.

Hasil survei yang telah dilakukan oleh tim pengabdian di Desa Karangkuten Kecamatan Gondang Kabupaten Mojokerto ditemukan bahwa pelaku UMKM masih banyak yang belum memiliki pemahaman mengenai pajak terutama belum memahami perhitungan pajak yang harus dibayar serta belum memahami pembuatan pelaporan pajak. Dalam melakukan penghitungan pajak dikenal dengan istilah akuntansi pajak. Menurut Agoes dan Trisnawati (2013) Akuntansi Pajak tidak memiliki standar seperti akuntansi keuangan yang diatur oleh Ikatan Akuntan Indonesia (IAI) dalam standar StandarAkuntansi Keuangan (SAK). Akuntansi Pajak hanya digunakan untuk mencatat transaksi yang berhubungan dengan perpajakan, berbeda dengan akuntansi komersial yang disusun berdasarkan SAK, sehingga untuk keperluan perpajakan maka akuntansi komersial disesuaikan dengan peraturan perpajakan yang berlaku di Indonesia.

Sebagai dasar regulasi pelaku UMKM dalam menyusun laporan keuangan Ikatan Akuntan Indonesia (IAI) telah menerbitkan aturan khusus yang disebut Standar Akuntansi Keuangan Entitas Tanpa Akuntabilitas Publik (SAK-ETAP). Dalam Bab 1 SAK-ETAP mengenai ruang lingkup, mengatur bahwa standar ini digunakan untuk entitas tanpa akuntabilitas publik. Entitas tanpa akuntanbilitas publik adalah entitas yang tidak memiliki akuntabilitas publik signifikan dan tidak menerbitkan laporan keuangan untuk tujuan umum bagi pengguna eksternal (Agoes dan Trisnawati, 2013).

Wajib Pajak UMKM dikenakan Pajak Penghasilan yang bersifat final dengan tarif $0.5 \%$ dari peredaran bruto setiap bulan. Dalam menghitung jumlah peredaran bruto usaha, pengusaha umkm harus menghitung seluruh peredaran bruto yang diperoleh termasuk usaha cabang (Waluyo, 2016). Penghasilan yang diperoleh oleh pelaku UMKM berasal dari keuntungan atau laba. Menurut Reeve, dkk (2009) keuntungan atau laba adalah selisih anatara uang yang diterima dari pelanggan atas barang atau jasa yang dihasilkan, dan biaya yang dikeluarkan untuk input yang digunakan guna menghasilkan barang atau jasa. Laporan keuangan yang telah disesuaikan dengan peraturan perpajakan dinamakan laporan keuangan fiskal. Tujuan utama dari pelaporan keuangan fiskal untuk menyajikan informasi sebagai bahan menghitung besarnya penghasilan kena pajak. Dalam sistem self assessment, wajib pajak harus menghitung sendiri utang pajaknya sehingga laporan keuangan itu sangat membantu perhitungan (Isroah, 2013). Berdasarkan permasalahan yang dihadapi mitra, maka dalam kegiatan pengabdian ini dilakukan kegiatan penyuluhan, pelatihan dan pendampingan terhadap mitra dengan harapan para pelaku UMKM dapat melakukan pengitungan pajak maupun menyusun pelaporan pajak sehingga pelaku usaha kecil dan menengah dapat memenuhi kewajiban perpajakan

\section{METODE PELAKSANAAN}

Persoalan yang dihadapi oleh UMKM di desa Karangkuten Kecamatan Gondang Kabupaten Mojokerto adalah kurangnya pengetahuan mengenai cara pelaporan keuangan, penghitungan dan pelaporan pajak, sehingga tim memberikan solusi dengan memberikan penyuluhan, pelatihan dan pendampingan kepada pelaku UMKM mengenai penyusunan laoran keuangan menurut SAK-ETAP, penghitungan pajak berdasarkan laporan keuangan yang telah disusun oleh pelaku UMKM dan diseuaikan dengan peraturan perpajakan yang berlaku di Indonesia, serta penyusunan pelaporan perpajakannya. Metode pelaksanaan kegiatan pengabdian ini antara lain:

1. Penyuluhan

Sebelum tim melakukan pelatihan mengenai penghitungan dan pelaporan perpajakan, tim terlebih dahulu memberikan pemahaman mengenai pentingnya penyusunan laporan keuangan bagi UMKM yang baik dan benar, sebagai dasar penghitungan pajak dan pelaporan pajak.

2. Pelatihan

Setelah diberikan pemahaman mengenai pencatatan keuangan dan perpajakan, selanjutnya tim memberikan pelatihan. Pelatihan yang diberikan kepada pelaku UMKM meliputi penyusunan laporan keuangan, perhitungan pengenakan pajak penghasilan dan pelaporan pajak penghasilan.

3. Pendampingan

Setelah kedua tahap dilakukan, tahap terakhir yang dilakukan oleh tim pengabdian yaitu pendampingan kepada pelaku UMKM di Desa 
Karang Kuten Kecamatan Gondang Kabupaten Mojokerto. Pendampingan dilakukan oleh tim pengabdian untuk mengetahui keberhasilan program yang ditawarkan. Proses pendampingan dilakukan dengan cara diskusi antara tim dengan mitra. Hal ini dilakukan untuk mengetahui hambatan-hambatan yang dialami oleh mitra selama melakukan penyusunan laporan keuangan maupun penghitungan pajak penghasilan sehingga tim dapat memberikan solusi kepada mitra.

\section{HASIL DAN PEMBAHASAN}

Sebelum dilakukannya pelatihan, tim terlebih dahulu menejlaskan materi mengenai pelaporan keuangan dan pelaporan perpajakan secara sederhana. Tim memberikan pemahaman mengenai tujuan serta manfaat yang akan diperoleh pelaku UMKM apabila melakukan pencatatan akuntansi serta memberikan materi mengenai komponen laporan keuangan secara sederhana. Setelah menjelaskan mengenai laporan keuangan selanjutnya tim pengabdian menyampaikan materi yang berkaitan dengan perpajakan UMKM. Tim memberikan pemahaman kepada pelaku UMKM mengenai pentingnya pelaporan pajak usaha karena berdasarkan pada hasil survey menunjukkan kesadaran pelaku UMKM mengenai pajak masih kurang, hal ini ditunjukan dari 10 pelaku UMKM hanya 2 (dua) pelaku UMKM yang secara rutin melaporkan penghasilan yang diterima setiap tahunnya. Dengan adanya sosialisasi diharapkan kesadaran pelaku UMKM mengenai pajak meningkat. Tim memberikan menyampaikan materi peraturan-peraturan perpajakan khususnya bagi pelaku UMKM. Dimana tarif Pajak Penghasilan Final untuk UMKM (WP Peraturan Pemerintah 23 Tahun 2008) saat ini sebesar $0.5 \%$.

Setelah tim memberikan pemahaman mengenai pelaporan keuangan dan pelaporan perpajakan secara sederhana, selanjutnya diberikan pelatihan. Dari hasil pelatihan yang diberikan oleh tim pengabdian, pelaku UMKM telah mampu menyusun laporan keuangan secara sederhana dan menyusun pelaporan keuangan yang telah disesuaikan dengan peraturan perpajakan serta telah memperoleh bukti pemotongan pajak secara online. Pelaku UMKM diberikan pelatihan untuk membuat pencatatan sederhana atas transaksi bisnisnya, meliputi pembuatan jurnal, buku besar sampai dengan menyusun laporan posisi keuangan dan laporan laba rugi secara sederhana. Pelaku UMKM sangat berantusias saat mengikuti pelatihan.

Pelatihan kedua yang diberikan oleh tim pengabdian adalah mengenai pelaporan perpajakan. Tim mengajarkan bagaimana menyusun laporan keuangan yang telah disesuaikan dengan per- aturan perpajakan, karena terdapat perbedaan pengakuan atas pendapatan dan biaya menurut akuntansi dan menurut fiskal sehingga perlu dilakukannya rekonsiliasi fiskal untuk mengetahui penghasilan kena pajak (PKP). Tim memberikan contoh kasus sederhana yang mudah dipahami oleh pelaku UMKM untuk mempermudah menyusun rekonsiliasi fiskal. Pelatihan selanjutnya yaitu perhitungan penghasilan kena pajak (tarif pajak $0.5 \%$ ). Setelah dilakukan perhitungan tim pengabdian juga melakukan pelatihan mengenai pelaporan pajak secara online. Dalam praktek ini tim terlebih dahulu memberikan contoh penyusunan laporan keuangan maupun penghitungan pajak penghasilan serta laporannya. Langkah berikutnya tim menyediakan kertas kerja bagi mitra untuk mencatat transaksi bisnisnya maupun kertas kerja untuk membuat laporan fiskal dan melakukan penghitungan pajak penghasilan.

Selama kegiatan pelatihan pembuatan laporan keuangan, penghitungan pajak penghasilan, tim tidak hanya menyediakan buku akuntansi yang nanti akan digunakan mitra untuk mencatat setiap transaksinya, tetapi tim pengabdian juga melakukan pelatihan dengan memanfaatkan teknologi sederhana yang tidak menyulitkan peternak bebek sehingga peternak bebek dapat memanfaatkan teknologi tersebut secara maksimal. Adapun pemanfaatan teknologi melalui Microsoft excel. Selanjutnya tim melakukan pelatihan peyusunan laporan fiskal dan penghitungan $\mathrm{PPh}$ final yang dikenakan kepada pelaku UMKM. Selama 1 bulan, mitra telah menyusun laporan keuangan sederhana meliputi penerimaan dan pengeluaran kas, laporan penjualan, laporan laba-rugi serta menghitung pajak penghasilan.

Kegiatan pengabdian kepada pelaku UMKM di Desa Karang Kuten Kecamatan Gondang Kabupaten Mojokerto dilakukan selama 1 (satu) bulan. Hasil yang dihasilkan dalam kegiatan pengabdian ini adalah hasil analisis penghasilan dan penghitungan pajak penghasilan. Adapun hasil pelatihan ini:

a) Pelaku UMKM di Desa Karang Kuten Kecamatan Gondang Kabupaten Mojokerto memiliki peredaran bruto tahun 2018 sebesar $\mathrm{Rp}$. 175.000.000,00

b) Peredaran pada Januari 2019 sebesar Rp. 15.000.000,-

c) Karena peredaran usaha tahun 2018 total < 4,8milyar, maka dikenakan pajak final.

d) Pajak bulan Januari 2019 adalah Rp. 15.000.000,- x $0.5 \%=$ Rp. 75.000 dilaporkan ke KPP

Dalam pelaksanaan kegiatan pengabdian ini, mitra diberikan pelatihan mengenai penyusunan 
laporan keuangan sederhana sehingga diketahui berapa peredaran bruto pelaku UMKM. Menurut ketentuan PP No. 46 Tahun 2013 bahwa pengusaha atau Wajib Pajak yang dikelompokkan sebagai usaha mikro, kecil dan menegah maksimal mempunyai peredaran $\mathrm{Rp}$ 4.800.000.000,- dalam setahun. Tarif PPh final yang dikenakan pada pelaku UMKM sebesar $0.5 \%$ dari peredaran bruto setiap bulan.

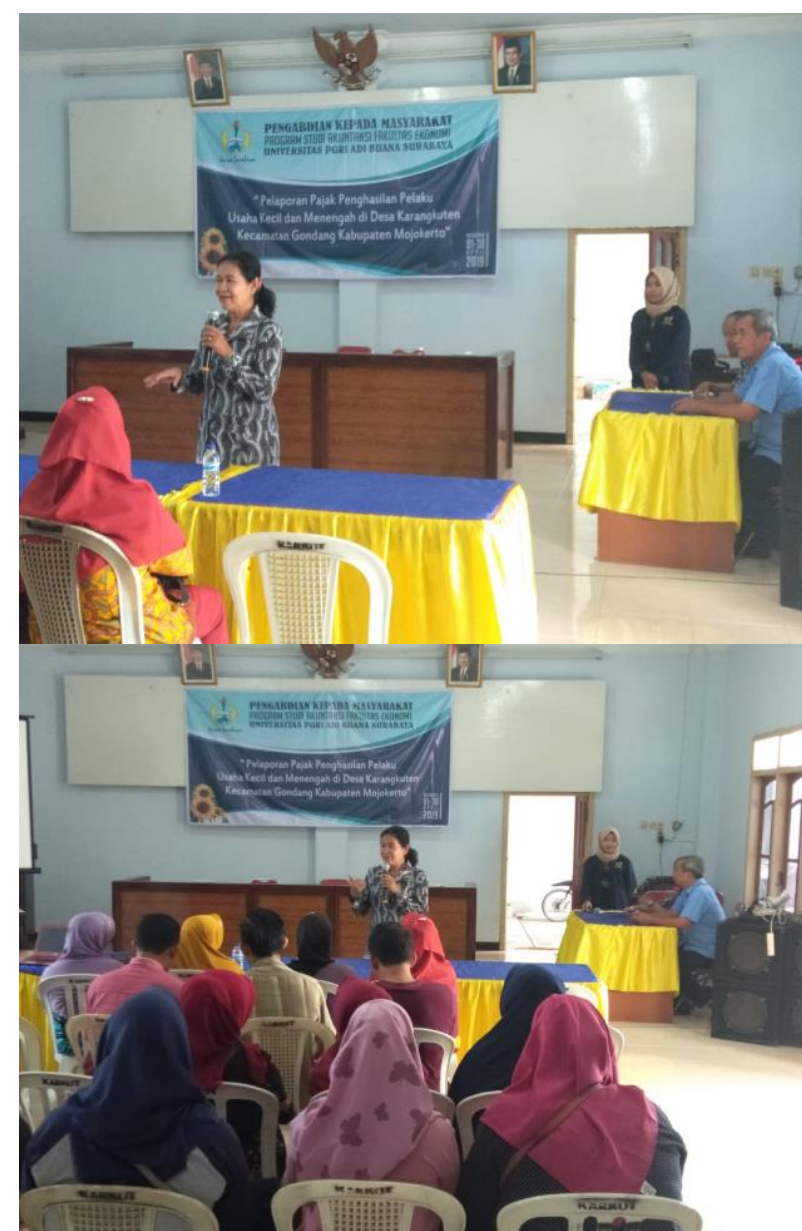

Gambar 1. Penyuluhan kepada warga Desa Karang Kuten, Kec. Gondang, Kab. Mojokerto

\section{KESIMPULAN}

Setelah dilakukannya pelatihan dan pendampingan kepada peternak bebek Desa Karang Kuten, dapat disimpulkan bahwa mitra (peternak bebek) telah mampu melakukan penyusunan laporan keuangan dan menghitung pajak penghasilan secara mandiri. Adapun saran kegiatan ini adalah mitra dapat konsisten melakukan pencatatan dan pelaporan akuntansi dan fiskal, serta penghitungan pajak penghasilan sehingga mitra dapat ikut serta dalam menjalankan kewajibannya dalam membayar pajak.

\section{UCAPAN TERIMA KASIH}

Tim pengabdian Fakultas Ekonomi mengucapkan terima kasih atas pendanaan internal dari Lembaga Penelitian dan Pengabdian Masyarakat Universitas PGRI Adi Buana Surabaya yang telah diberikan kepada tim pengabdian, sehingga program-program yang ditawarkan oleh tim kepada mitra (peternak bebek) berjalan dengan lancar serta mitra dapat memperoleh manfaat atas program yang ditawarkan yang dilakukan oleh tim pengabdian.

\section{DAFTAR PUSTAKA}

Agoes, Sukrisno dan Trisnawati, Estralita. 2013. Akuntansi Perpajakan. Edisi 3. Jakarta: Salemba Empat

Ikatan Akuntan Indonesia. 2015. Pernyataan Standar Akuntansi Keuangan. Jakarta: Salemba Empat

Isroah. 2013. Penghitungan Pajak Penghasilan Bagi UMKM. Jurnal Nominal. Vol. 1, No. 1

Peraturan Pemerintah Nomor 46 Tahun 2013 tentang Pajak Penghasilan untuk UKM

Reeve, James M., dkk. 2009. Pengantar Akuntansi Adaptasi Indonesia. Buku 1. Jakarta: Salemba Empat

Waluyo. 2016. Akuntansi pajak. Edisi 6. Jakarta: Salemba Empat 